\title{
Triple Discordances in Receptor Status During Breast Cancer Local Progression and Metastases: Case Report and Literature Review [Erratum]
}

Martuszewski A, Paluszkiewicz P, Nowak M, Szewczyk K, Staszek-Szewczyk U. Onco Targets Ther. 2020;13:103 43-10349.

The authors have advised that the Acknowledgment section on page 10348 of the published paper is incorrect. This error was introduced by the Editorial staff during the publication process. The acknowledgment statement should read as follows:

\section{Acknowledgment}

The publication was prepared under the project financed from the funds granted by the Ministry of Science and Higher Education in the "Regional Initiative of Excellence" programme for the years 2019-2022, project number 016/RID/2018/19, the amount of funding 11998 121.30 PLN.

\section{Publish your work in this journal}

OncoTargets and Therapy is an international, peer-reviewed, open access journal focusing on the pathological basis of all cancers, potential targets for therapy and treatment protocols employed to improve the management of cancer patients. The journal also focuses on the impact of management programs and new therapeutic agents and protocols on patient perspectives such as quality of life, adherence and satisfaction. The manuscript management system is completely online and includes a very quick and fair peer-review system, which is all easy to use. Visit http://www.dovepress.com/ testimonials.php to read real quotes from published authors. 